of the directly elected medical members over the non-elected medical members (paragraph 9.13).

(27) The Congress should elect Panels to deal with specific subjects, including education, discipline, penal cases, finance, registration, E.E.C., and the "sick doctor" and related problems (paragraph 9.14).

(28) The congress will have ultimate responsibility for its own financial affairs. It should therefore appoint a finance panel with power to restrain other panels, and even the congress itself, from making decisions involving finance against the finance panel's recommendation or without proper consideration. The finance panel should be chaired by the treasurer, who should be a directly elected member of the congress (paragraph 10.4).

(29) The finance panel must have a majority of directly elected members since the major source of income will continue to be the profession itself (paragraph 10.4)
(30) Adequate publicity must be given to the financial affairs of the congress for the information of the profession and the public (paragraph 10.4).

(31) It is essential that the finance panel should receive expert advice on investments and investment policy, and on the management of the assets of the Congress (paragraph 10.8).

(32) Regular channels of communication should be established between the congress and individual members of the profession, and also between the B.M.A. and the congress for the transmission of the views of the profession as a whole on matters of general importance (paragraph 11.2).

(33) The congress should appoint a public relations officer (paragraph 11.3).

(34) Although there is a continuing need for a registrar of the congress, the appointment of a medical secretary responsible for the non-disciplinary functions might prove of value (paragraph 11.4).

\title{
From the Committees
}

\section{Joint Consultants Committee}

The following report is based on information supplied by the Foint Consultants Committee.

The Joint Consultants Committee met on 24 July at B.M.A. House. Sir Kenneth Robson was in the chair.

\section{Central Manpower Committee}

A report from the Central Manpower Committee covering the period May 1972 to June 1973 was received by the J.C.C., which appoints the professional representatives to the C.M.C. The effect on manpower calculations of the unknown number of N.H.S. honorary contracts held by academic and Medical Research Council staff was being looked at urgently. The C.M.C. was initiating a redistribution of registrars and senior registrars with a view to a more equitable distribution, in particular between teaching and non-teaching hospitals. A conference had been held, which representatives of medical education and medical manpower bodies had attended, to secure better liaison.

\section{Consultants in Accident and Emergency Medicine}

A limited number of appointments of consultants in accident and emergency medicine have been made as a pilot scheme after joint consideration by the J.C.C. and the Department, and additional posts have been advertised by hospital boards. The J.C.C. agreed that there was a need for a formal training programme for doctors wishing to apply for such posts.

\section{Hospital Waiting Lists}

The Department of Health had proposed that advice should be issued to hospital boards on the reduction of inpatient waiting times. The Committee recognized the need for this but believed that insufficient weight had been attached to lack of facilities and resources, and there was a tendency to criticize consultants for matters outside their control.

\section{Community Hospitals}

A draft memorandum of guidance on community hospitals had been discussed by the Committee and the Department of Health and it was anticipated that it would be issued shortly. The J.C.C. had some reservations on particular points and hoped that the guidance given would be sufficiently flexible to enable adjustments to be made in the light of experience.

\section{N.H.S. Reorganization}

The Committee hoped that the working party set up by the Secretary of State for Socia Services, which would represent health service and local authority interests and examine the practical arrangements for the provision of social work support for the health service by local authorities, would be open to receive evidence. The Committee was concerned that while a local authority retained the right to make a medical appointment (though it was envisaged that it would normally use the services of doctors appointed by the area health authority) the A.H.A. had no corresponding right to appoint a social worker

\section{Stomatology}

The status of stomatology was causing difficulty as a result of the decision of the nonspecialists section of the European Union of Medical Specialists to extend the scope of that specialty to include maxillofacial surgery and to exclude non-medically qualified consultants in dental surgery from membership. The Royal College of Surgeons will convene a meeting of British representatives on non-specialist sections in the interested specialties to discuss the problem.

\section{Reports of Meetings}

The J.C.C. agreed that a reporter might attend future meetings of the Committee and that reports could appear in the B.M.f.

\section{B.M.A. Action on Joint Liaison Committees in England}

The B.M.A. is establishing a B.M.A. Steering Committee in each new N.H.S. area (Supplement, 28 April, p. 23) and has appointed representatives for consultation in each new N.H.S. region. Regional and area health authorities will soon be appointed in shadow form; in the meantime they are in operation in embryo form as joint liaison committees (Supplement, 19 May, p. 53). If a doctor wishes to put forward any point to his regional or area J.L.C. he should contact his local unit of the B.M.A.

\section{Corrections}

Scottish Council for Postgraduate Medical Education Publications

Career Guidance 1973 and Postgraduate Papers1970-72 are available free of charge from the Scottish Council for Postgraduate Medical Education, 8 Queen Street, Edinburgh EH2 1JE, not from H.M.S.O as stated in the Supplement, 28 July, p. 17 